\title{
More innovation to reconcile consumers with fruits
}

The last two editorials were dedicated to encouraging initiatives in the fruit sector. It was the launch of the Specialty Crop Research Initiative in the United States, and the commitment of the European Commission for increasing fruit consumption in schools in Europe.

We are now pleased to welcome the launch of the Group of Scientific Interest on Fruits (GIS Fruits) in France, on February 29th, 2012, during the last Paris International Agricultural Show.

This initiative brings together 22 French partners from research, such as INRA and CIRAD; higher education, such as Montpellier SupAgro and Agrocampus Ouest; technical institutes, professional organisations and institutional bodies.

Its objective is to meet the challenges of the fruit sector better through innovation based on an enhanced dialogue between all actors.
The number and diversity of participants engaged in this initiative are a guarantee of its success, aiming at integrating the issues of production, processing and consumption of fruits in all their forms.

It is worth mentioning the words of Bruno Lemaire, the French Minister of Agriculture, during the launch ceremony. He recalled the need to work to reconcile consumers with fruits as a way to promote better nutrition and to continue to resist obesity and asked for more aggressive research in this perspective, including new consumption modes, more diverse products and improved supply chains.

These are all areas that the journal Fruits aims to promote through its editorial line.

Dr. Jacky Ganry Scientific Director of Fruits

\section{Plus d'innovation pour réconcilier les consommateurs avec les fruits}

Les deux derniers éditoriaux ont été consacrés à des initiatives très encourageantes pour le secteur des fruits. C'était le lancement de l'Initiative de recherche sur les cultures spéciales aux États-Unis et l'engagement de la Commission Européenne pour une consommation accrue de fruits dans les écoles en Europe.

Maintenant, nous devons saluer le lancement du Groupe d'Intérêt Scientifique sur les Fruits (GIS Fruits) en France, le 29 février 2012, lors du dernier Salon international de l'Agriculture de Paris.

Cette initiative réunit 22 partenaires français de la recherche, avec l'INRA et le CIRAD ; de l'enseignement supérieur, avec Montpellier SupAgro et Agrocampus Ouest ; des instituts techniques, des organisations professionnelles et des organismes institutionnels.

Son objectif est de mieux relever les défis du secteur des fruits grâce à l'innovation et à un renforcement du dialogue entre tous les acteurs.
Le nombre et la diversité des participants engagés dans cette initiative sont un gage de sa réussite, visant à intégrer les questions de production, de transformation et de consommation de fruits sous toutes leurs formes.

Il convient de mentionner les mots de Bruno Lemaire, ministre français de l'Agriculture, au cours de la cérémonie de lancement. Il a rappelé la nécessité d'œuvrer pour réconcilier les consommateurs avec les fruits afin de promouvoir une meilleure nutrition et de continuer à résister à l'obésité et il a souhaité une recherche plus offensive dans une telle perspective, y compris sur les nouveaux modes de consommation, sur des produits plus diversifiés et sur l'amélioration des chaînes de distribution.

Ce sont autant de domaines que la revue Fruits entend promouvoir au travers de sa ligne éditoriale.

Dr. Jacky Ganry Directeur scientifique de Fruits 